\title{
The New Online English-Georgian Maritime Dictionary (NEGMD): Current State of the Project
}

\author{
Anna Tenieshvili, Foreign Languages Department, \\ Batumi State Maritime Academy, Batumi, Georgia \\ (a.tenieshvili@bsma.edu.ge)(anna_tenieshvili@yahoo.com)
}

\begin{abstract}
My practical training at the Maritime Transport Administration of Georgia in 2018 inspired the project of compiling the NEGMD. The project was boosted by an international grant of the European Lexicographic Infrastructure (ELEXIS), which led to an invitation to visit the Instituut voor Nederlandse Lexicologie in Leyden, the Netherlands.

The aim of this report on the compilation of the NEGMD is to show the state of this project from a practical point of view using concrete examples of terminological entries.

The project includes two main issues: the compilation of the dictionary itself and the coinage of new maritime terms in Georgian to fill the existing lexical/terminological gaps. It is of great importance for the field of maritime education and training in Georgia, for the whole maritime economy of the country and for the development of the Georgian language and, consequently, for the fields of Georgian linguistics and lexicography.

All issues related to this project including the criteria according to which it is being compiled and the information each terminological entry of the dictionary comprises, will be thoroughly covered. Perspectives on future dictionary development will be presented, illustrating it by concrete examples from the NEGMD.
\end{abstract}

Keywords: DICTIONARY COMPILATION, GUIDING PRINCIPLES, TERMINOLOGICAL ENTRIES, COINAGE OF GEORGIAN MARITIME TERMINOLOGY

Opsomming: Die Nuwe Aanlyn Engels-Georgiese Maritieme Woordeboek (NEGMD): Stand van die projek. My praktiese opleiding by die Maritieme Vervoeradministrasie van Georgië in 2018 het die projek om die NEGMD saam te stel, geïnspireer. Die projek is bevorder deur 'n internasionale toekenning van die Europese Leksikografiese Infrastruktuur (ELEXIS), wat gelei het tot 'n uitnodiging om die Instituut voor Nederlandse Lexicologie in Leiden, Nederland, te besoek.

Die doel van hierdie verslag oor die samestelling van die NEGMD is om die stand van die projek uit ' $n$ praktiese oogpunt te toon met konkrete voorbeelde van terminologiese inskrywings.

Die projek omvat twee hoofkwessies: die samestelling van die woordeboek self en die skepping van nuwe seevaartterme in Georgies om die bestaande leksikale/terminologiese gapings te vul. Dit is van groot belang vir die vakgebiede van maritieme opvoeding en opleiding in Georgië, vir die algehele maritieme ekonomie van die land en vir die ontwikkeling van die Georgiese taal, en dus vir die vakgebiede Georgiese linguistiek en leksikografie.

Alle kwessies rakende hierdie projek, insluitende die kriteria waarvolgens dit saamgestel 
word en die inligting wat elke terminologiese inskrywing van die woordeboek bevat, sal deeglik gedek word. Perspektiewe op toekomstige woordeboekontwikkeling sal aangebied word deur dit met konkrete voorbeelde uit die NEGMD te illustreer.

Sleutelwoorde: WOORDEBOEKSAMESTELLING, RIGLYNE, TERMINOLOGIESE INSKRYWINGS, NUUTSKEPPINGS IN GEORGIESE MARITIEME TERMINOLOGIE

\section{Introduction}

The aim of the present report is to familiarize readers with the progress of work on the compilation of the NEGMD. The dictionary represents a pioneering project both for the fields of Georgian lexicography and Georgian maritime terminology. The reason for this is that previously, all maritime dictionaries that had been compiled in Georgia were translational dictionaries, giving one or several meanings of a particular term. The dictionary subject of this report has an explanatory character that is conditioned by the fact that term definitions are given both in English and Georgian, and also for the purpose of illustrating the terminology usage, the terms are provided with corpora examples. The information given in each terminological entry is organized in such a way that the student and general user are given an idea and understanding of the particular concept expressed by means of terms in the language. The compilation of this dictionary is guided by a terminological rather than a lexicographic approach. Since this is a specialized dictionary, the approach is therefore onomasiological, rather than semasiological, i.e. starting from the concept and moving to naming the concept by means of a term.

The project also addresses the coinage of missing Georgian maritime terminology with the purpose of filling existing lexical gaps, an issue that is especially relevant for terms of maritime navigation. During this process, I identify terms that do not have Georgian equivalents and through cooperation with the Georgian Linguistics Institute and the State Language Chamber of Georgia terms will be coined and added to the dictionary.

\section{The NEGMD project}

Several contributing factors led to the start of the NEGMD project. They can be formulated and explained in the following way:

One of the priorities of the Georgian economy and sustainable development is to develop the maritime field. The development of the maritime field is especially important for the economics of the country and this field should be developed in several directions. They are: ports, logistics, maritime education and training that comprises navigation, maritime transportation, maritime management and marine engineering. The importance of the maritime field is confirmed by the fact that this field makes a large contribution to the country's 
economy and budget and therefore its development is of strategic importance.

Nowadays, the maritime field is an international field in which various countries of the world fulfil various functions. Georgia mainly fulfils a transit function and owing to its geostrategic location throughout history, the country has formed a link between Europe and Asia. Georgia, being an important centre of maritime education, can increase its role in the preparation of highly qualified seafarers since maritime education plays a significant role in establishing Georgia in the international domain and in the development of the country's economy.

The idea of the project of compiling the NEGMD occurred to me after I had my practical training at the Maritime Transport Administration of Georgia in 2018. This practical training was obligatory since, in addition to my PhD in English Philology, I received an MSc in Maritime Affairs majoring in Maritime Education and Training from the World Maritime University (WMU).

As part of the above-mentioned project I received an international grant from the European Lexicographic Infrastructure (ELEXIS) in 2019 and being the receiver of the grant program, I was invited to the Instituut voor Nederlandse Lexicologie in Leyden, the Netherlands. In order to compile a dictionary that will contain various types of information including definitions, corpus examples, some encyclopedic information, related words, etc., it was necessary to conduct some research work, to pay attention to advice of specialists experienced in similar work. As my dictionary is intended to have both terminological and lexicographic features, the opinions of terminologists and lexicographers are to be taken into consideration when composing entries and compiling the dictionary as a whole. In addition to the dictionary compilation, the purpose of my work is to conduct research in order to fill in the lexical gaps existing in maritime terminology in Georgian.

During work on the NEGMD project, I am guided by the following recommendations for the compilation of specialized dictionaries that were given by L'Homme (2006: 182) in the article "The Processing of Terms in Dictionaries":

- Dictionaries should consider user needs and include highly specialized but also less specialized items;

- Terminologists or specialized lexicographers should make more use of evidence found in corpora as a basis for taking decisions about terms;

- Dictionaries should include more data on terms (e.g., collocations, valence patterns, images);

- Bilingual and multilingual dictionaries should account for interlinguistic differences;

- Dictionaries should describe relationships between terms;

- Specialized dictionaries should contain encyclopedic or pragmatic information;

- Definitions should be structured in order to display key conceptual components. 
The project includes consideration of and work on maritime terminology. As maritime terminology is divided into two parts, general maritime terminology and specific maritime terminology, I started the compilation of the dictionary from work on general maritime terminology. At the present stage, the project comprises more than 1000 terminological entries, the majority of which are general maritime terms.

The following criteria and principles guide the compilation of the dictionary:

1. The terminology comprises the following maritime subfields: maritime navigation, marine mechanical engineering, marine electrical engineering, logistics, economics of maritime transport, mechanization of port operations, cargo work and maritime law;

2. At the current stage I consider and work on simple terms, as for terminological lemmas, they will form the following stage of the dictionary compilation work;

3. Each terminological entry includes definitions and corpus examples;

4. Each term is considered from the viewpoint of its monosemantic nature.

During dictionary compilation, I am guided by the international standard of terminology processing and enter all information related to terminological entries into a specially developed online platform.

As mentioned in Tenieshvili (2020: 485-491) the NEGMD project is very important to Georgia as a sovereign country, for Georgian linguistics and lexicography and for the Georgian maritime semantic field. Georgia is a sovereign country now, and terminology is one of the means of establishing the country as an independent state. Although maritime terminology is the most globalized semantic field in the world, each country, especially maritime nations like Georgia, must have its own maritime terminology. It is especially important for reaching the following aims:

1. Stimulation for developing Georgian maritime terminology;

2. Application of the developed maritime terminology in textbooks, maritime documentation and materials;

3. Economy of space and facilitation of understanding among specialists and students of the maritime field;

4. Improvement of the system of maritime education and consequently of the national maritime industry;

5. Contribution to the lexicography of Georgian;

6. Development of the lexicography of the maritime semantic field;

7. Establishing a basis for a Georgian maritime corpus with further integration of the Georgian maritime corpus into the general corpus of the Georgian language;

8. General contribution to Georgian linguistics. 
It would be expedient to give an idea of the NEGMD project by demonstrating terminological entries that have already been developed in the present report:

\section{accommodation $n$}

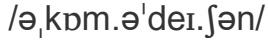

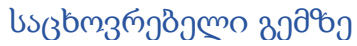

fitted with cabins and catering facilities for offshore crews

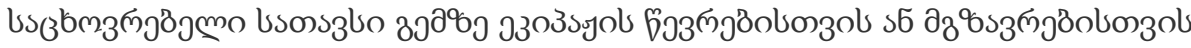

Corpus examples

Accommodation was clean but basic.

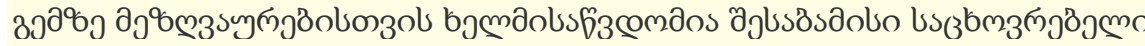
озйомдัо.

\section{afterpeak $n$}

/af-ter-peek/

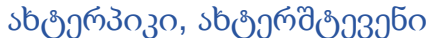

the extreme after part of the interior of a hull, especially that part below the water immediately forward of the sternpost (opposed to forepeak)

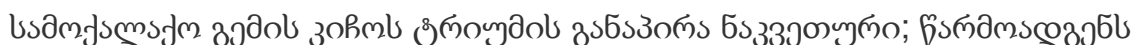

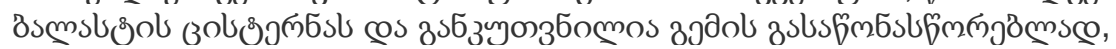

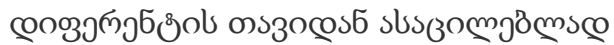

\section{Corpus examples}

Forepeak tanks are at the fore end of the hull and afterpeak tanks are at the after end.

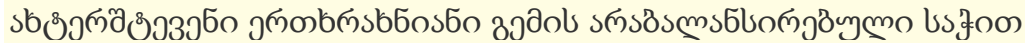

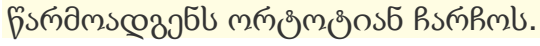

\section{anchorage $n$}

['ænkərid3]

мелgstssczman

place where a boat is or can be anchored

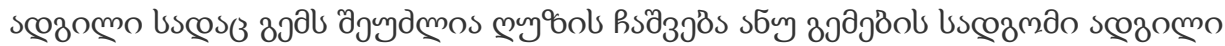

Corpus examples

We are in between the Hospital and the Alaska Regional Medical Plaza. If you are approaching anchorage from the NORTH on the Glen Highway, turn left at the 2nd set of lights onto Airport Heights Road.

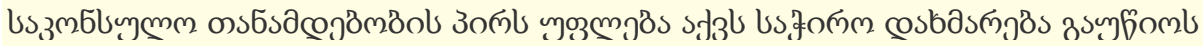

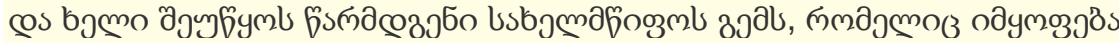

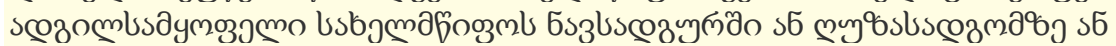

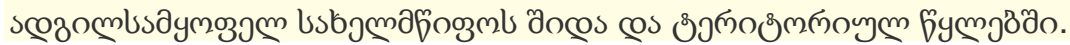




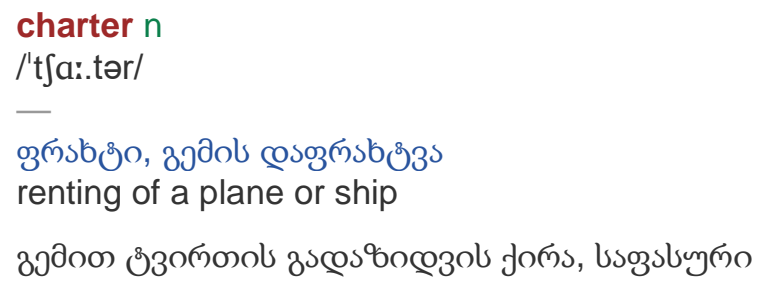

\section{helm $n$}

[helm]

\section{gु)}

handle or tiller, in large ships the wheel, by which the rudder is managed, sometimes extended so as to include the whole steering gear

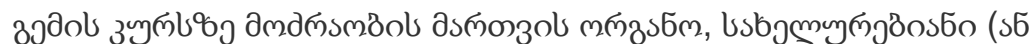

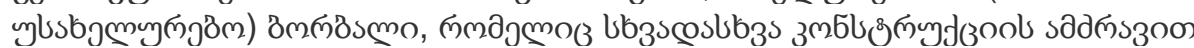

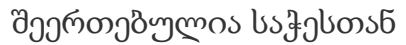


Corpus examples

Very few helms were sailing their boats anywhere near to the limit of their craft's capability, including some old hands.

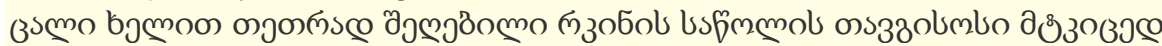

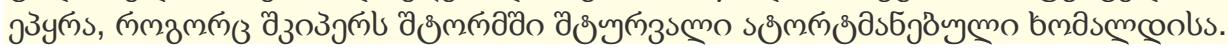

(extracted from: The NEGMD)

Along with the compilation of the dictionary itself, there is a second issue: the coinage of Georgian maritime terminology. There are different methods of terminology creation. Sometimes even calques can be used. In my opinion, as English is the official language of the maritime field established by the International Maritime Organization (IMO) based in London, it would be expedient if calquing takes place from the English language. That would contribute to the internationalization of terminology and this, in its turn, would facilitate communication between specialists of the maritime field. It is also important to ensure the coexistence of national terms and terms that have recently entered the language.

I think that when creating Georgian maritime terminology, specialists should be guided by the rules of Georgian and it would be better to avoid calquing taking into consideration international linguistic rules at the same time. Such a combined approach would help in reaching a certain balance in this issue. As an example, I would like to mention that owing to linguistic specifics of the English language there exist terms based on the noun + noun model in it, yet it does not mean that grammatical calques should be borrowed in line with lexical calques too.

In my opinion, the issue of coinage of the Georgian maritime terminology implies several organizational issues, such as:

1. Revision of existing maritime dictionaries and glossaries;

2. Selection of a policy for the coinage of maritime terms;

3. Selection of methods for the coinage of maritime terms;

4. Organization of a team.

Perfection and adoption of maritime terminology will contribute to the development of the entire maritime field and also its different subfields. It is very important to ensure the improvement of the academic level of maritime specialists.

\section{Conclusion}

Compilation of the New Online English-Georgian Maritime Dictionary is of utmost importance for the field of maritime education and training and for the whole maritime field of Georgia. It will stimulate the educational process in Georgian maritime educational institutions, provide much new information and increase comprehension of maritime issues, contributing to a better com- 
prehension of maritime phenomena by Georgian maritime students in their native language. In addition, the project and all issues discussed in this report will contribute to the fields of lexicography and linguistics in Georgia, as it will enable native Georgians to study and comprehend maritime phenomena in their native language via correspondent terms and not only on the basis of English-English explanations, the practice that exists today.

The issues of compilation of the maritime dictionary and refining of Georgian maritime terminology are very important for the development of maritime education and for the establishment of Georgia in the international maritime arena.

\section{References}

L'Homme, Marie-Claude. 2006. The Processing of Terms in Dictionaries: New Models and Techniques. A State of the Art. Terminology 12(2): 181-188

New Online English-Georgian Maritime Dictionary. Available at: https://www.lexonomy.eu/ zy44hrpwh/.

Tenieshvili, A. 2020. The New Online English-Georgian Maritime Dictionary Project. Challenges and Perspectives. Gavriilidou, Z., M. Mitsiaki and A. Fliatouras (Eds.). 2020. Proceedings of the XIX Euralex International Congress, Alexandroupolis, Greece, 7-11 September 2021. Volume 1: 485-491. Komotini, Greece: Democritus University of Thrace. Available at: https://euralex2020.gr/wpcontent/uploads/2020/11/EURALEX2020_ProceedingsBook-p485-491.pdf. 